\title{
VÕIMALIKKE PROTOEUROOPA SUBSTRAADI JÄLGI EESTI KEELE DENDRONÜÜMIDES ${ }^{1}$
}

\author{
SVEN-ERIK SOOSAAR
}

\begin{abstract}
Annotatsioon. Alates Paul Ariste töödest 1950. aastatel on peetud võimalikuks, et eesti keeles on säilinud sõnu, mis on pärit keelest, mida kõneldi Eesti alal enne soomeugrilist keelt rääkinud hõimu saabumist Läänemere äärde. Kui Ariste pakutud substraattüvede tähendusvaldkonnad olid peamiselt maastikuelementide, kehaosade ja loomade nimetused, siis käesolevas artiklis vaadeldakse võimalikke substraattüvesid eesti ja laiemalt lõunaläänemeresoome keelte dendronüümides. Esitatakse viis eesti keele puunimetust (pärn, kuker(puu), hala(paju), lõhmus, paaks(puu)), mis võivad nii fonotaktiliste, semantiliste kui levikuliste kriteeriumite põhjal kuuluda substraattüvede hulka.
\end{abstract}

Võtmesõnad: etümoloogia, keeleajalugu, keelekontaktid, protoeuroopa substraat, dendronüümid

\section{Protoeuroopa substraadi varasemast käsitlusest}

Protoeuroopa substraadist eesti keeles ja läänemeresoome keeltes üldisemalt hakkas 1950. aastatel rääkima Paul Ariste, kui oli selgunud, et Kunda kultuuri kandjad ei saanud olla soomeugrilased. Ta pakkus välja, et teatud maastiku, fauna ja kehaosade nimetused võiksid pärineda enne soomeugrilaste saabumist Eesti alal kõneldud keelest (Ariste 1956, 1962, 1971). Hilisema uurimistöö käigus on leitud osale Ariste pakutud substraatsõnadest germaani või balti etümoloogia, kuid mitmed neist on siiani parema etümoloogiata. Märkimisväärne on, et Ariste pakutud substraattüvede seas ei ole mitte ühtegi taimenimetust, seega ka puunimetust (Kendla, Viikberg 2016).

Artikkel on valminud Eesti Teadusfondi järeldoktoriprogrammi PUTJD842 „Protoeuroopa substraat lõunaläänemeresoome keelte sõnavaras“ ja Helsingi Ülikooli toetusel. Tänan Riho Grünthali ja anonüümseid retsensente väärtuslike nõuannete eest. 
Kuigi tähelepanuväärsel osal läänemeresoome tüvedest puudub etümoloogia, on mitmed tänapäeva fennougristidest keeleajaloolased, nt Petri Kallio ja Janne Saarikivi, seisukohal, et läänemeresoome keeltes protoeuroopa substraati ei ole või vähemalt pole võimalik seda kindlaks teha (Saarikivi 2004, 2006; isiklik suhtlus Petri Kallioga). Olen seisukohal, et seni kuni hulk läänemeresoome tüvesid on ilma selge etümoloogiata, on õigustatud oletus, et vähemalt osa neist pärineb nn protoeurooplaste keelest.

Siinses uurimuses on piirdutud vaid eesti keeles ja teistes lõunaläänemeresoome keeltes (vadja ja liivi) esinevate puunimetustega. Võimalikud kontaktid protoeurooplaste ja varase läänemeresoome keele kõnelejate vahel pidid toimuma tänapäeva Eesti ja Läti aladel, kust sai läänemeresoome keelte lahknemine alguse. Lõunaeesti oli esimene läänemeresoome algkeelest lahknenud haru, millele järgnes liivi (Sammallahti 1977: 132-133; Viitso 1985; Kallio 2014; Lang 2018: 219jj; Prillop jt 2020: 24-26). On võimalik, et teatud osa oli lahknemistes ka substraatkeelt kõnelenud, kuid soome-ugri keelele üle läinud rahvastikul. Seejuures on tõenäoline, et põlisasukate keelest jõudsid substraadina soomeugrilaste keelde nende puude nimetused, mis olid kas siinsele looduskeskkonnale iseloomulikud ja/või olid neil aladel juba enne soomeugrilaste saabumist elanud inimestele olulised oma raviomadustelt või tarbepuiduna.

\section{Häälikulised muutused lõunaläänemeresoome keeltes}

Lõunaläänemeresoome keeltes on toimunud mitmeid häälikulisi muutusi, mille puhul võib kahtlustada naaberkeelte või substraatkeele mõju. Karl Pajusalu on analüüsinud lõunaläänemeresoome keelte, eriti lõunaeesti ja liivi keele häälikulisi muutusi, mis eristavad neid põhjaläänemeresoome keeltest (Pajusalu 2012, vt ka Kallio 2016). Nendeks erijoonteks on ümardamata keskvokaal, velaarne vokaalharmoonia, rõhuta vokaalide reduktsioon, afrikaadid ${ }^{2}$, jalaisokroonia, monosüllaabiline jalg, konsonantide palatalisatsioon, vältevaheldus, piiratud laadivaheldus ja rõhumuutused. Ta märgib, et liivi ja lõunaeesti selgem eristumine on vastavuses nende

2 Afrikaadid esinevad ka põhjaläänemeresoome keeltes (karjala, lüüdi, vepsa), kuid on seal hiljem tekkinud klusiili ja sibilandi ühendist. Läänemeresoome algkeele puhul ei ole afrikaatide esinemises täielikku üksmeelt (Kallio 2016; Prillop jt 2020: 97). 
asendiga Baltikumi alal ning toetab võimalikke substraatnähtusi (Pajusalu 2012: 219).

Üsna keeruline on eristada substraatkeele mõjul toimunud häälikulisi muutusi neist, mis on toimunud naaberkeelte, peamiselt balti keelte mõjul. Teada on, et substraatkeele jäljed säilivad paremini teatud semantilistes sõnavarakihtides, eelkõige neis, mis on seotud loodusliku keskkonnaga, kus keelt räägiti. Selline sõnavara puudub sageli sisserännanute keeles ning seetõttu võib see säilida n-ö võõrsõnade või laenudena ka siis, kui põlisrahvas on oma keele hüljanud uustulnukate keele kasuks. Häälikulised muutused toimuvad kogu sõnavaras, selle päritolust sõltumata. Balti keelte puhul on nende häälikuline süsteem rekonstrueeritav, mis annab võimaluse nende võimalikku mõju hinnata. Tundmatut päritolu substraatkeele mõju häälikulisele süsteemile võib tuvastada vaid nende häälikuliste joonte kaudu, mis pole omased soome-ugri keeltele ega teadaolevatele naaberkeeltele (peamiselt balti keeltele), sest tundmatu keele häälikulised ja ka muud iseärasused on samuti tundmatud. On võimalik, et Eesti alal räägiti mitut erinevat keelt, kuid ala väiksuse ning maastikuliste iseärasuste (lauskmaa) tõttu on vähetõenäoline, et siin räägiti palju erinevaid keeli, nagu seda sageli tehakse mägistel aladel (nt Kaukaasias), ning lähtuda võiks eeldusest, et enne soomeugrilaste saabumist räägiti Eesti alal vaid üht keelt.

Varase läänemeresoome ehk lääneuurali algkeele häälikuline koostis erines väga vähe uurali algkeele häälikusüsteemist, mistõttu on tänapäeval üldtunnustatud seisukoht, et varase läänemeresoome algkeele ajaline kaugus uurali algkeelest ei saanud olla kuigi suur. Seevastu hilises läänemeresoome algkeeles oli toimunud mitmeid häälikulisi muutusi, eriti just kaashäälikusüsteemis (Kallio 2007, 2016). Nende muutuste põhjuseks on peetud enamasti võõrmõju. Lauri Posti superstraaditeooria järgi on läänemeresoome keeltes germaani ja balti superstraat (Posti 1953). Tänapäeval on see teooria kindlalt ümber lükatud (Kallio 2000, 2007). Siiski on germaani substraati läänemeresoome keeltes oletanud arheoloogiliste andmetele tuginedes hiljuti arheoloog Valter Lang (2018: 196jj). 


\section{Substraatkeeltest meil ja mujal}

Substraatkeeli võib olla nelja tüüpi: 1) elus keel, nt iiri substraat inglise keele iiri murdes; 2) välja surnud keel, mis on suguluses mõne tänapäeva keelega, nt soome-ugri (sh merja) substraat vene murretes (Tkachenko 1985; Saarikivi 2000, 2006) ja saami substraat põhjasoome murretes ${ }^{3}$ (Aikio 2004); 3) välja surnud keel, millel ei ole teadaolevaid sugulaskeeli, nt etruski keel, millest on säilinud lühikesi tekste ja mis on jätnud jälje substraatsõnadena ladina keeles ja selle tütarkeeltes; 4) välja surnud keel, mis on säilinud vaid substraadina, nt substraat germaani keeltes, protoeuroopa substraat saami keeltes (Aikio 2004, 2012). Erinevalt kolmanda rühma substraatkeeltest pole neljanda rühma keelte korral säilinud ajaloolisi allikaid substraatkeele kohta.

Eesti keeles ja teistes läänemeresoome keeltes esinev substraat kuulub eeldatavasti neljandasse tüüpi, mistõttu on selle kindlakstegemine keerulisem. Näiteks on teise tüüpi kuuluval merja keelel jälgi ajaloolistes allikates ning selle leviala on suhteliselt täpselt piiritletud. Seetõttu on võimalik võrrelda merja substraati sisaldavaid vene murdeid nende murretega, kus seda substraati ei ole. Läänemeresoome keeltes esineva arvatava substraatkeele kohta ajaloolised allikad aga puuduvad ning samuti ei saa seda keelt täpsemalt lokaliseerida. Substraat on tekkinud juba hilises läänemeresoome algkeeles, enne tänapäeva keelte lahknemist.

Tundmatu päritoluga substraatsõnavara on oletatud ka teistes uurali keeltes ning paljudes teiste keelkondade keeltes. Uurali keeltest on kõige selgemalt täheldatud substraatsõnavara saami keeltes ja nganassaani keeles. Ante Aikio on saami keeltes kindlaks teinud mitusada tõenäolist substraatsõna, mis on semantiliselt iseloomulikud kohalikele geograafilistele ja kliimaoludele. Tuginedes eeldusele, et saami keeled levisid põhja poole rauaajal, olles kontaktis algskandinaavia keele kõnelejatega, arvab Aikio, et mitteuurali keeli kõneldi Skandinaavia põhjaosas veel meie ajaarvamise esimesel aastatuhandel. (Aikio 2004, 2012)

Nganassaani keele leksikon erineb märkimisväärselt nii geograafiliselt lähedastest põhjasamojeedi rühma kuuluvatest eenetsi ja neenetsi keeltest kui ka teistest samojeedi keeltest. Nganassaani keeles esinevat

3 Keeled muutuvad pidevalt, mistõttu substraadi allikaks olnud saami keel ei saa olla ükski tänapäeval kõneldav saami keel, kuid tõenäoliselt oli see tänapäeva saami keeltele lähedane keelekuju. 
tundmatut päritolu substraati on alles hiljuti hakatud põhjalikumalt uurima (Kaheinen 2021).

Tundmatu päritoluga substraatsõnavara esineb ka mitmes indoeuroopa keeles, nt germaani keeltes. Kalevi Wiik püüdis tõestada, et seal on tegemist soome-ugri päritolu substraadiga, kuid tema väiteid ei ole üldiselt aktsepteeritud (Kallio jt 1998; Grünthal 2003; Kallio 2004). Hiljem on mõnede tundmatut päritolu germaani tüvede sarnasusele samatähenduslike eelkreeka päritolu kreeka tüvedega (nt alggermaani *arwìt- 'hernes' kr erebinthos 'hernes') ja semiidi tüvedega juhtinud tähelepanu Guus Kroonen ja arvanud, et tegu võib olla ühisest protoeuroopa substraatkeelest pärit tüvedega. Samuti leiab ta, et mõned tüved paistavad olevat sama substraatset päritolu nii germaani kui läänemeresoome keeltes, nt e lõoke alggermaani *laiwarikō. (Kroonen 2012)

Selge tundmatut päritolu substraat esineb ka kreeka keeles. Kuigi see substraat on oma vanuselt võrreldav oletatava läänemeresoome protoeuroopa substraadiga, on kreeka keele vanimad kirjalikud allikad üle 1000 aasta vanemad läänemeresoome kirjalikest allikatest, mistõttu on substraatsõnade keelde jõudmise ja selle keele dokumenteerimise ajaline vahe tunduvalt väiksem. Meil on võimalik jälgida kreeka keele arengut kirjalike allikate põhjal rohkem kui 2000 aasta jooksul, koos mükeene kreeka keelega üle 3000 aasta jooksul. Seetõttu tuleb läänemeresoome keeltes substraadi kindlakstegemisel tugineda vaid tänapäeva keelte sõnavara siserekonstruktsioonile ja toponüümikale.

Läänemeresoome algkeelde saab rekonstrueerida üle 1000 tüve, millel pole teada vasteid idapoolsetes soome-ugri keeltes ning millele pole leitud ka laenuallikaid (Rätsep 1983 [2002]; Metsmägi jt 2013). Huno Rätsepa andmetel on eesti kirjakeeles 601-847 läänemeresoome tüve (sh 204-228 onomatopoeetilis-deskriptiivset tüve), lisaks 400-515 liivi-soome tüve (sh 177-191 onomatopoeetilis-deskriptiivset tüve) ja 1075-1152 (sh 431-489 onomatopoeetilis-deskriptiivset) eesti tüve (Rätsep 1983 [2002]: 66-68). Kui arvata onomatopoeetilis-deskriptiivsed tüved välja, jääb umbes 1200 läänemeresoome omatüve, mille seas on ka arvatavad substraattüved. Kindlasti ei saa kõiki neid pidada substraattüvedeks, sest nende hulgas on ka 1) tüved, mille vasted kaugemates sugulaskeeltes on kadunud; 2) tuletuse, tüvede koondumise ja muude meetoditega soome-ugri tüvedest loodud uued tüved; 3) seni kindlaks tegemata laentüved. Siintoodud esimese rühma tüvesid ei ole sisuliselt võimalik eristada substraattüvedest, 
sest kui kaugemates sugulaskeeltes pole tüve säilinud, pole ka võimalik sugulust kuidagi kindlaks teha. Fonotaktiliste iseärasuste alusel võib siiski sõnu sellest rühmast elimineerida. Teise ja kolmanda rühma tüvesid saab etümoloogilise uurimistöö abil tulevikus kindlaks teha. Substraattüved võivad olla moondunud kujul säilinud ka rahvaetümoloogia tõttu muudetud häälikulise kujuga nimedes ja liitsõnades, kus tundmatu tähendusega nime- või sõnaosa on hakatud tõlgendama tuntud tüve variandina.

Onomatopoeetilis-deskriptiivsete tüvede puhul ei saa välistada nende substraatset päritolu, kuid kuna onomatopoeetilised ja deskriptiivsed tüved võivad tekkida spontaanselt, siis on äärmiselt raske tõestada nende substraatset päritolu. Samas moodustab näiteks soome keele etümoloogilistes sõnaraamatutes selliste tüvede osakaal 10-20\% (Heikkonen 2018: 209). Eesti etümoloogilises sõnaraamatus on selliste tüvede märkimiseks kasutatud väljendit ,häälikuliselt ajendatud tüvi“. Selline etümoloogia on 520 märksõna puhul, neist 458 märksõnal on see ainuke päritoluseletus (Metsmägi jt 2013: 319-320). Seega moodustavad need tüved eesti etümoloogilise sõnaraamatu 5403 sisuartiklist vastavalt 9,6-8,5\%, mida on küll vähem kui soome etümoloogilistes sõnaraamatutes (SKES ja SSA), kuid see võib olla tingitud peale koostajate ja toimetajate teoreetiliste seisukohtade erinevuse ka sõnaraamatute erinevatest koostamispõhimõtetest.

Juhul kui substraatkeel oli uurali algkeele sugulaskeel ehk eeluurali haru, mis oli lahknenud eeluurali keelest vähem kui 1000 aastat enne lääneuurali algkeele kõnelejate jõudmist Läänemere äärde, oleks substraatsõnade eristamine tunduvalt keerulisem. Tõenäoliselt oleks nende keelte häälikulised ja fonotaktilised erinevused ebapiisavad selleks, et neid tänapäeva keeltes tuvastada.

Aikio on kasutanud tundmatut päritolu substraadi tuvastamiseks viit kriteeriumi: 1) kvantitatiivne kriteerium (palju etümoloogiata tüvesid); 2) struktuuriline kriteerium (arvatavad substraatsõnad sisaldavad algkeelele ebatavalisi fonoloogilisi või morfoloogilisi struktuure); 3) irregulaarse häälikuvastavuse kriteerium; 4) semantiline kriteerium (tundmatut päritolu tüved esinevad peamiselt semantilistel väljadel, mis on substraatsõnavarale tüüpilised); 5) onomastiline kriteerium (arvatavatel substraattüvedel on paralleele tundmatut päritolu kohanimedes) (Aikio 2004, 2012). Järgnevalt vaatame, kuidas need kriteeriumid toetavad võimalikku substraati lõunaläänemeresoome puunimetustes. 


\section{Puid tähistavad arvatavad substraattüved}

Botaaniline sõnavara on sageli üks neid semantilisi välju, milles esineb rohkem substraatkeelest pärit tüvesid. Näiteks loetleb Robert Beekes kreeka keeles 178 substraatpäritolu tunnustega sõna, mis on seotud flooraga ja mis jäävad oma hulga poolest alla vaid faunaga seotud sõnadele, mida on esitatud 180 (Beekes 2014: 54-90). Seetõttu on ka põhjust läänemeresoome protoeuroopa substraadi otsingutel alustada floora ja faunaga. Käesolevas töös käsitlen flooraga, kitsamalt puudega seotud sõnavara.

Huno Rätsep (1983 [2002]: 67) on kirjutanud, et lingvistilised kriteeriumid protoeuroopa laenude eraldamiseks läänemeresoome sõnavarast puuduvad. Enn Ernits on siiski leidnud, et Ariste pakutud substraatkeelest pärit tüvedele on iseloomulikud teatud häälikuühendid ja fonotaktilised jooned. Ta toob välja neli häälikulist joont: 1) sõnad, milles sisalduva konsonantühendi esimene või viimane komponent on $r:-r C-/-C r-, 2)$ sõnad, mis algavad häälikuga $h-, 3$ ) sõnad, mis sisaldavad konsonantühendit - $h C$-, ning 4) afrikaate sisaldavad sõnad. (Ernits 1979, 2017)

Siinkohal vaatlen eelnimetatud tunnustele vastavaid läänemeresoome tüvesid, millel teadaolev laenuallikas või soome-ugri etümoloogia puudub või on see ebakindel. Eesti kirjakeele puunimetustest vastavad neile tunnustele järgmised: pärn, kuker(puu), hala(paju), lõhmus ja paaks(puu) (murretes ka paatspuu, paatsapuu, paatsip).

\subsection{Pärn (Tilia cordata)}

eP, eM pärn, eL pähn, lv pärrna, lvS pärrn, päern, vdj - (pärnäne, pärnene, pernene, pärnine 'pärnane, pärnapuust'; vadja vasted esinevad vaid rahvaluules genitiivivormis, vt VKS). Tüvi esineb ka soome murretes (pärnä 'pärn; jalakas') ja isuri keeles (pärnä). Tüvi on läänemeresoome keeltes piiratud levikuga ja samas tähenduses on rohkem kasutusel tüvi lõhmus (vt allpool) ja niine/puu, mille esimene osis on läänemeresoome-permi tüvi niin (EES: 311-312). On arvatud, et puunimetus on seotud soome idamurretes esineva sõnaga pärnä 'ümmarguse v pikliku kujuga, sageli servast paisunud kõrgendik' (SSA 2: 459).

Läänepoolne levik läänemeresoome keeleareaalis, puuduv laenuetümoloogia ning unikaalne häälikuvastavus eL - $h n-\sim \mathrm{eP}-r n$ - viitavad tüve võimalikule substraatpäritolule. Märkimisväärne on ka see, et häälikuliselt 
sarnast kohanime Pärnu on Ariste (1981: 17) samuti pidanud võimalikuks substraatnimeks.

\subsection{Kuker-(puu) (Berberis vulgaris)}

Kukerpuu on Eestis looduslikult levinud paiguti, enamasti Lääne-Eestis (Kukk 2004: 48). Seetõttu on nimetust registreeritud vähestest kihelkondadest, peamiselt Lääne-Eestist (Kaa Pöi Noa Mar Aud Äks) (VMS; EMS 3: 989). Sarnane tüvi esineb ka murdesõnades kukespuu (Vän KJn SJn) (EMS 3: 990) ja kukispuu (Rid Lih Kse) (EMS 3: 992). Samatüvelist sõna kukerkuusk on tuntud kuslapuu, vereva kontpuu või põldosja tähenduses (Jäm Khk Krj Pha Vll Pöi Muh Khn Kõp Trv) (VMS; EMS 3: 988). Seda on peetud tuletiseks samast tüvest, mis on murdesõnas $k u k k$ 'käbi; linakupar; nutt, nupukujuline õisik' (T ja V) ja mille vasted on vdj kukka 'lill; õis', sm kukka 'lill', is $k u k k a$ 'lill', krjP $k u k k a$ 'lill', krjA kukku 'lill', või sõnast kukk 'kanalise isaslind' (EEW IV: 1025-1026; EES sub kuker-2'; Uibo 2011: 537). Seda seletust ei saa välistada, kuid murdesõna $k u k k$ levik ei kattu absoluutselt tüve kuker- levikuga ning nimetusel puudub ka selge motivatsioon. Seetõttu on sarnasus tüvega $k u k k$ pigem juhuslik ja tõenäolisem on tüve substraatne päritolu. Teistes lõunaläänemeresoome keeltes vasteid tüvele kuker- ei leidu.

\subsection{Hala-(paju) (Salix acutifolia)}

Halapaju on levinud laial alal Euroopas ja Lääne-Siberis ning on sarnane teiste pajuliikidega. Eesti keelealal esineb kujul halapaju (Jõe Rei Pst Nõo Har Lut), halapai, hala(k)puu (Nõo Kan Rõu Plv Vas Se Lei Lut) (EMS). Wiedemanni sõnaraamatus leidub ka liitsõna halakask vaevakase tähenduses (Wiedemann 1893: 217). Võimalik, et siin on rahvaetümoloogiliselt sõnaosa hala- seostatud tüvega hala $(\mathrm{ma})$ 'kurtma, kaeblema'.

Tüvi esineb ka liivi keeles: alāb alābõz 'remmelgas'. Liivi keeles on $h$ kadu reeglipärane (Kallio 2016: 42).

Soome sõnad halava ja halapaju on liitsõnad osistega hala(va)- ja vastavalt puu või paju. Soome halava on levinud edelamurdes, Satakunna, Peräpohjola ja Põhja-Karjala murretes; halapaju on tuntud ka Häme ja Kymenlaakso murretes (SMS). Sellel tüvel on kaheldav balti etümoloogia: < leedu atžala 'noor oks, võrse' (Suhonen 1989: 217-219; Junttila 
2015: 101). Leedu atžala tundub olevat liitsõna, mille esiosa on prefiks at- ja teine osa on tuletatud tüvest žalias 'roheline'. Sellest balti tüvest on pärit ka ee haljas (eP aljas, eL (h)aílass $\sim(h)$ aĺlaśs, (h)aĺass $\sim(h)$ aĺaśs $)$, vdj allaz 'toores, roheline; haljas, läikiv', lv ọlaz 'roheline'. Selles tüves on $l$ palataliseeritud, mistõttu ei saa tüvi hala- samast tüvevariandist tuleneda.

hala-tüve on seostatud ka soome tüvega salava (Salix fragilis) 'remmelgas', kuid nende omavaheline seos on ebaselge (SSA 3: 147).

Kuna tüvel hala-puudub kindel laenuetümoloogia, ei saa välistada selle substraatpäritolu, mida häälikuliselt toetab ka sõnaalguline $h$-.

\subsection{Lõhmus (Tilia)}

Pärna tähistamiseks on üldlevinud ka nimetus lõhmus, mille vasted on vdj (kreevini) lähämus, eL lõhmus, sm lehmus, krjLü lehmuz, vps l’ehmuz. Põhja-Eestist ei ole tüve registreeritud. Tüve lõhmus kohta on arvatud, et selle algne tähendus võis olla 'pehme' ning et tüvi võib olla seotud soome ja karjala murdesõnaga lehmus 'paks ja lõtv' ning sm murdesõnaga lehmottaa 'lodevalt istuda' ja olla algselt deskriptiivne (SSA 2: 58; EES). Sellele tüvele pakutud mordva vastete (er l'evš 'niin' ja mo l'evaš 'niin') häälikuvastavus ei ole reeglipärane. Häälikuühend - $h m$ - esineb eesti kirjakeeles 57 tüves (EES). Enamik neist on eesti etümoloogilise sõnaraamatu määratluse järgi läänemeresoome või eesti häälikuliselt ajendatud tüved (nt jahmatama, klohmima, kahmama, lahmama, ohmu, ?puhm, rohmima, rähm, sahmama, ähm, ühmama). Nende seas on ka mõned balti laenud (ehmes, pahmas, rihm, rühm, vehmer, ?võhm), üks baltisaksa (tohman) ja üks vene laen (pohmelus). Omatüvedest on kaugemate sugulaskeelte vasted vaid tüvedel lehm (mordva), tuhm (saami), uhmer (mordva-mari), vihm (saami). Seega viitab häälikuühend $-h m-\left(<^{*}-\check{s} m-\right)$ enamasti tüve deskriptiivsele või laenulisele päritolule. Tüved, mille puhul kumbki variant ei ole tõenäoline ning mis kuuluvad substraatsõnavara tüüpilistele semantilistele väljadele, nagu nt lõhmus, puhm ja kühm, on suurema tõenäosusega pärit substraatkeelest.

4 Tüves uhmer on häälikuühend - $h m$ - tekkinud metateesi teel ja seda moodustavad konsonandid kuulusid alguses eri silpidesse $(<*$ šuma-re). 


\subsection{Paaks-(puu) (Frangula alnus)}

eP paakspuu (murretes ka paats-), lv pagāstmōrapū, sm paatsama. Paakspuu kasvab põõsana, kuid mõnikord võib ta kasvada ka väikeseks puuks. Mürgise taimena kasutatakse paakspuu koort ja marju rahvameditsiinis, sellega värviti ka lõnga. Väiksematest okstest vitsu kasutati väiksemate nõude vitsutamiseks, paakspuust lõhestati vikativitsu ja tehti tugevaid rehapulki. (Viires 1975: 130)

ALFEs on esitatud rekordilised kümme kaarti, et kujutada selle puunimetuse varieeruvust ja erinevaid nimeformante (ALFE 3: 449-463). Eesti murretes on registreeritud variandid paatsapuu (Kuu Hlj VNg Lüg Jõh VJg Sim IisK Iis Trm), paatspuu (IisR Saa Äks Vil Hls TMr), paatsip (Hls Krk), paaks(i)puu (LNg Rid Mar Kul Vig PJg), paaksnapuu, pahakspuu (pahaksipuu) (Jäm Khk Mus Kaa), pahaspuu (Jäm Ans Khk Khn Kad Sim), paaspuu (Kär Kaa Vll Phl), pahaksi (Khk Kaa), pavats (Lüg Jõh), paksempuu (Kuu KuuK), paksmaspuu (Kad), pasmaspuu (VMr), poaksmapuu (VMr) (VMS). Lõuna-Eestis esineb seega vaid tüvekuju paatsa-, Tartu ja Mulgi murdes ka paatsi-. Algne klusiili sisaldav tüvekuju *pakats- on säilinud vaid liivi, karjala ja vepsa keeles (ALFE 3: 454). Soome murretes on levinud ka erinevad tüve paja-sisaldavad nimetused (pajatin, pajahtin, pajakka, pajatati jne) (ALFE 3: 455-456).

Liivi keeles on puunimetuse esimest osist pagāst rahvaetümoloogiliselt seostatud läti sõnaga pagasts 'vald' (ALFE 3: 460). Läänemeresoome tüve saab rekonstrueerida kujul * pakats-, kuid ebaregulaarsed variandid viitavad võimalikule substraatsele päritolule. Ebaselge on ka selle tüve seos vadja keele samatähendusliku tüvega bragattsi, brägättsi. Liivi, vadja ja edelasoome murretes kasutatakse järelosisena sõna marjapuu. Eesti murretes esinevad paakspuu nimetuses ka eesliited kitse-/kitsi- (Plt Trm Kod Trm MMg Lai Pal Pst Hel Pil KJn SJn Äks Kõp Vil Hls Trv Krk TMr Ran Puh Võn Nõo Ote Rõn San Rõu Plv Räp Har Rõu Se Lei), soe- (Har), undimarja- (IisR) ja voho- (Kan Rõu Plv Vas Räp Se) (VMS). Teistes läänemeresoome keeltes kasutatakse samuti selle põõsa nimetuses erinevate loomade (kits, hunt, koer, madu) nimetusi (ALFE 3: 462).

Tüve häälikuline varieeruvus ja rekonstrueeritav afrikaat toetavad selle substraatset päritolu. 


\section{Kokkuvõte}

Eesti keeles võib vähemalt viie puunimetuse (pärn, kuker(puu), hala(paju), lõhmus, paaks(puu) $)^{5}$ puhul pidada tõenäoliseks nende protoeuroopa päritolu, võttes aluseks Ernitsa välja toodud neli häälikulist joont, mis on iseloomulikud arvatavatele protoeuroopa päritolu tüvedele, ja arvestades Aikio pakutud tundmatut päritolu substraatsõnavara kindlakstegemise kriteeriume. Saadud tulemus viitab sellele, et protoeuroopa päritolu sõnavara võib eesti keeles olla säilinud seniarvatust suuremal hulgal, seejuures ka floorat tähistavas sõnavaras, ning väärib edaspidist põhjalikumat süstemaatilist uurimist.

\section{Lühendid}

IisK - Iisaku (keskmurre), IisR - Iisaku (rannikumurre), KuuK - Kuusalu (keskmurre)

\section{Kirjandus}

Aikio, Ante 2004. An essay on substrate studies and the origin of Saami. Etymologie, Entlehnungen und Entwicklungen: Festschrift für Jorma Koivulehto zum 70. Geburtstag. Hrsg. Irma Hyvärinen, Petri Kallio, Jarmo Korhonen, Leena Kolehmainen. (= Mémoires de la Société Néophilologique de Helsinki 63.) Helsinki: Société Néophilologique de Helsinki, 5-34.

Aikio, Ante 2012. An essay on Saami ethnolinguistic prehistory. - A Linguistic Map of Prehistoric Northern Europe. Ed. by Riho Grünthal, Petri Kallio. (= Suomalais-Ugrilaisen Seuran Toimituksia 266.) Helsinki: SuomalaisUgrilaisen Seura, 63-117.

ALFE $=$ Atlas Linguarum Fennicarum. Itämerensuomalainen kielikartasto, 2007-2010. Päätoim. Tuomo Tuomi. Helsinki.

Ariste, Paul 1956. Mõningaid märkmeid „Eesti NSV ajaloo“ I köite kohta. Edasi 13. I.

Ariste, Paul 1962. Mõnda substraadist. - Keel ja Kirjandus 1, 13-17.

Ariste, Paul 1971. Die ältesten Substrate in den ostseefinnischen Sprachen. Sovetskoe finno-ugrovedenie 4, 251-258.

\footnotetext{
Lisaks on kirjakeeles kasutatud murdesõna ( $h$ )ong 'vana mänd' (EKSS), mis on registreeritud kirderannikumurdest ja idamurdest ning millel on läänemeresoome keeltest vasted vadja, soome, karjala, lüüdi ja vepsa keeles, kuid puuduvad liivi ja lõunaeesti keeles. Tüvi on laenatud ka vene murretesse. Kuigi liivist ja lõunaeestist pole tüve registreeritud, viitab lai levik mujal läänemeresoome alal tüve vanusele. $h$-algulisus on ka substraatsõna tunnus.
} 
Ariste, Paul 1981. Keelekontaktid: eesti keele kontakte teiste keeltega. (= Eesti NSV TA Emakeele Seltsi toimetised 14.) Tallinn: Valgus.

Beekes, Robert S. P. 2014. Pre-Greek. Phonology, Morphology, Lexicon. (= Brill Introductions to Indo-European Languages 2.) Leiden, Boston: Brill.

EES = Eesti etümoloogiline sõnaraamat, 2012. Koost. ja toim. Iris Metsmägi, Meeli Sedrik, Sven-Erik Soosaar. Peatoim. Iris Metsmägi. Eesti Keele Instituut. Tallinn: Eesti Keele Sihtasutus.

EEW = Julius Mägiste, 1982-1983. [2. tr 2000.] Estnisches etymologisches Wörterbuch I-XII. Helsinki: Finnisch-Ugrische Gesellschaft.

EKSS $=$ Eesti keele seletav sõnaraamat, 2009. 2. tr. Toim. Margit Langemets, Mai Tiits, Tiia Valdre, Leidi Veskis, Ülle Viks, Piret Voll. Tallinn: Eesti Keele Sihtasutus. https://www.eki.ee/dict/ekss.

EMS = Eesti murrete sõnaraamat, 1994-.. Toim. Mari Kendla, Mari-Liis Kalvik, Tiina Laansalu. Tallinn: EKSA. https://www.eki.ee/dict/ems/.

Ernits 1979= Э. Эрнитс 1979. К выявлению субстрата в прибалтийско-финских языках. - SFU 3, 129-135.

Ernits, Enn 2017. Sõna haaval. Emakeelest tehiskeelteni. (= Eesti Teaduste Akadeemia Emakeele Seltsi toimetised 75.) Tallinn: Emakeele Selts.

Grünthal, Riho 2003. Kielen muuttuminen on enemmän kuin kielikontaktien summa. - Tieteessä Tapahtuu 21 (5), 72-74.

Heikkonen, Katja 2018. Äännesymbolisen sanaston etymologioinnin ongelmia. - Peri orthotētos etymōn. Uusiutuva uralilainen etymologia. Toim. Sampsa Holopainen, Janne Saarikivi. (= Uralica Helsingiensia 11.) Helsinki, 203-228.

Junttila, Santeri 2015. Tiedon kumuloituminen ja trendit lainasanatutkimuksessa. Kantasuomen balttilaislainojen tutkimushistoria. Helsinki: Helsingin yliopisto.

Kaheinen, Kaisla 2021. Ettekanne „Substraatista nganasanissa“ Helsingi Ülikoolis 21.01.2021.

Kallio, Petri 2000. Posti's superstrate theory at the threshold of a new millennium. - Facing Finnic: Some Challenges to Historical and Contact Linguistics. Toim. Johanna Laakso. (= Castrenianumin toimitteita 59.) Helsinki, 80-99.

Kallio, Petri 2004. All that glitters is not gold. [Review of Kalevi Wiik, Eurooppalaisten juuret. Jyväskylä 2002.] - Finnisch-Ugrische Mitteilungen 26/27. Hamburg, 203-215.

Kallio, Petri 2007. Kantasuomen konsonanttihistoriaa. - Sámit, sánit, sátnehámit. (= Suomalais-Ugrilaisen Seuran Toimituksia 253.) Helsinki, 229-249.

Kallio, Petri 2014. The diversification of Proto-Finnic. - Fibula, Fabula, Fact. The Viking Age in Finland. Ed. by Joonas Ahola, Frog with Clive Tolley. (= Studia Fennica Historica 18.) Helsinki: Finnish Literature Society, $155-168$. 
Kallio, Petri 2016. Historical phonology from Proto-Finnic to Proto-Livonian. - Eesti ja soome-ugri keeleteaduse ajakiri. Journal of Estonian and Finno-Ugric Linguistics 7 (1), 39-65. http://dx.doi.org/10.12697/ jeful.2016.7.1.02

Kallio, Petri, Jorma Koivulehto, Asko Parpola 1998. „Kantagermaanin suomalais-ugrilainen substraatti“: edelleen perusteeton hypoteesi. - Tieteessä Tapahtuu 16 (3), 45-48.

Kendla, Mari, Jüri Viikberg 2016. Protoeurooplaste keelepärandist. - Emakeele Seltsi aastaraamat 61. Peatoim Mati Erelt. Tallinn: Emakeele Selts, 135-154. http://dx.doi.org/10.3176/esa61.06

Kroonen, Guus 2012. Non-Indo-European root nouns in Germanic: Evidence in support of the agricultural substrate hypothesis. - A Linguistic Map of Prehistoric Northern Europe. Ed. by Riho Grünthal, Petri Kallio. (= Suomalais-Ugrilaisen Seuran Toimituksia 266.) Helsinki: SuomalaisUgrilainen Seura, 239-260.

Kukk, Toomas 2004. Eesti taimede kukeaabits. Tallinn: Varrak.

Lang, Valter 2018. Läänemeresoome tulemised. (= Muinasaja teadus 28.) Tartu: Tartu Ülikooli Kirjastus.

Metsmägi, Iris, Meeli Sedrik, Sven-Erik Soosaar 2013. Eesti kirjakeele tüvevara päritolu arvudes. - Keel ja Kirjandus 5, 313-332.

Pajusalu, Karl 2012. Phonological innovations of the southern Finnic languages. - A Linguistic Map of Prehistoric Northern Europe. Ed. by Riho Grünthal, Petri Kallio. (= Suomalais-Ugrilaisen Seuran Toimituksia 266.) Helsinki: Suomalais-Ugrilaisen Seura, 201-224.

Posti, Lauri 1953. From Pre-Finnic to late Proto-Finnic. - Finnisch-Ugrische Forschungen 31, 1-91.

Prillop, Külli, Karl Pajusalu, Eva Saar, Sven-Erik Soosaar, Tiit-Rein Viitso 2020. Eesti keele ajalugu. Tartu: Tartu Ülikooli Kirjastus.

Rätsep, Huno 1983 [2002]. Eesti kirjakeele tüvevara päritolu. - Keel ja Kirjandus 10, 538-548.

Saarikivi, Janne 2000. Kontaktilähtöinen kielenmuutos, substraatti ja substraattinimistö. - Virittäjä 104 (3), 393-415.

Saarikivi, Janne 2004. Is there Palaeo-European interference in western branches of Uralic? - Suomalais-Ugrilaisen Seuran Aikakauskirja 90. Helsinki, $187-214$.

Saarikivi, Janne 2006. Substrata Uralica: Studies on Finno-Ugrian Substrate in Northern Russian Dialects. Tartu: Tartu University Press.

Sammallahti, Pekka 1977. Suomalaisten esihistorian kysymyksiä. - Virittäjä, $81(2), 119-135$.

SMS $=$ Suomen murteiden sanakirja. https://kaino.kotus.fi/sms/. 
SSA = Suomen sanojen alkuperä. Etymologinen sanakirja, 1992-2000. Toim. Erkki Itkonen, Ulla-Maija Kulonen. Helsinki: Suomalaisen Kirjallisuuden Seura, Kotimaisten kielten keskus.

Suhonen, Seppo 1989. Baltische und slavische Etymologien. - SuomalaisUgrilaisen Seuran Aikakauskirja 82. Helsinki, 211-221.

Tkachenko 1985 = Орест Ткаченко 1985. Merjanski jazyk. Kiev: Naukova Dumka.

Uibo, Udo 2011. Etümoloogilisi märkmeid (XI). Suvejuttu er-liitsõnadest. - Keel ja Kirjandus 7, 536-542.

Viires, Ants 1975. Puud ja inimesed. Tallinn: Valgus.

Viitso, Tiit-Rein 1985. Läänemeresoome murdeliigenduse põhijooned. - Keel ja Kirjandus 7, 399-404.

VKS = Vadja keele sõnaraamat. https://www.eki.ee/dict/vadja/.

VMS = Väike murdesõnastik. https://www.eki.ee/dict/vms/.

Wiedemann, Ferdinand 1893. Ehstnisch-deutsches Wörterbuch. Red. Jakob Hurt, St. Peterburg: Kaiserliche Akademie der Wissenschaften. 


\title{
Possible traces of a Proto-European substrate in Estonian dendronyms
}

\author{
SVEN-ERIK SOOSAAR
}

The article discusses possible traces of the hypothetical substrate language spoken on the territory of present-day Estonia before the arrival of Finno-Ugric speaking tribes. It is shown that, taking into consideration the four phonotactical features of the substrate lexicon described by Enn Ernits and the criteria for determination of substrate vocabulary of an unknown source language described by Ante Aikio, there are at least five word stems among Estonian dendronyms that do not have a trustworthy etymology outside the Finnic group. These stems show phonotactical features described by Ernits and meet the criteria described by Aikio.

We can conclude that the Estonian dendronyms pärn, kuker-, paats-, hala-, and lõhmus are probable Proto-European substrate words.

Keywords: etymological research, language history, language contacts, ProtoEuropean substrate, dendronyms

Sven-Erik Soosaar

Eesti Keele Instituut

Roosikrantsi 6

10119 Tallinn

svenerik.soosaar@eki.ee 